\title{
TEACHING ACADEMIC WRITING IN A FLIPPED CLASSROOM
}

\author{
M.V.Tsytovich, Maria.Tsytovich@gmail.com, \\ G.F. Boronenko, gboronenko@yandex.ru \\ South Ural State University, Chelyabinsk, Russian Federation
}

\begin{abstract}
In the context of a common educational space formation, international collaboration based on the principle of academic mobility is becoming of primary importance for universities and other higher educational institutions. Proficiency in English is the necessary requirement for international collaboration in education. To resolve the contradiction between the need for academic mobility and the low level of language proficiency, various language training courses are being initiated in educational institutions. In the South Ural State University, a Center of Academic Writing, educational program "Lingua", and other courses for lecturers, postgraduates and undergraduates have been launched where teaching is conducted according to traditional methodology and using innovative technologies. The aim of the article is to analyze the existing advanced technologies and approaches to language teaching and to justify the choice of blended learning approach for teaching academic writing at the university. The article reveals the essence of the flipped classroom model, its advantages and disadvantages.

The authors describe the experience of using the flipped classroom technology teaching the writing for research papers at the South Ural State University.

Keywords: academic mobility, blended learning, flipped classroom, international collaboration, academic writing.
\end{abstract}

\section{Introduction}

In the context of globalization and a common educational space formation, international collaboration based on the principle of academic mobility is becoming a primary focus of universities and other higher educational institutions activities. Academic mobility is an opportunity for students, lecturers, administrative and management staff of higher educational institutions to "move" from one institution to another in order to exchange experience and cultural traditions, gain new opportunities, overcome national isolation and acquire a common European perspective [11].

International collaboration in the field of science and education is developing in the following direction: taking part at international conferences, lecturing in a foreign language, organizing and conducting scientific and scientificmethodological seminars, round table discussions with foreign experts, joint research with foreign scientists, scientific-methodical and educationalmethodical advanced training and participation in international seminars, international competitions and grants $[9,10]$. The South Ural State University (SUSU) cooperates with the universities of the USA, Europe, Asia and China, in the following areas:

- symmetric academic mobility of students,

- short-term language and professional internships,
- double diploma programs (Russian and English).

It is obvious that the academic mobility of university teaching stuff is not implemented in full. One of the reasons is the insufficient level of the English language proficiency, as it is the language of international collaboration. To resolve this contradiction, various language courses have been organized in SUSU for the university lecturers, among them Lingua courses where not only English for everyday communication is taught, but also specialized courses, such as English for international conferences, academic correspondence and others. In addition, the Center of Academic Writing has been opened at the University. Its activity is aimed at expanding the international publication activity of the teaching staff, providing tutor and translator services, along with the specialized academic writing training courses [6]. Academic writing is a part of academic English. This kind of English you need for studying and doing research is rather different from everyday English. It may be used to: describe an object or situation; describe a process or how something works; explain something. Much of academic English is about expressing the relationship between ideas. Although the language may be more complex than everyday English, good academic writers aim to be as clear, precise and simple as possible $[17,18]$. It is difficult to 


\section{Теория и методика профессионального образования}

give overall 'rules' and distinctive features but it is different from everyday English in terms of:

- vocabulary and expressions;

- the types of texts used (for instance essays, reports, research articles or summaries);

- how these texts are structured and organised.

Extension courses for different levels of language proficiency, including the course "English language: Research Paper" for upper-intermediate students have been organized at the Center of Academic Writing in SUSU.

Initially, the training was carried out according to the traditional model, and we faced the following difficulties: lack of class hours, different levels of language proficiency and different pace of mastering the material, different subject areas, and inability to attend all classes because of the workload of students. Therefore, the search for new approaches to academic writing teaching in the direction of intensification and individualization of the educational process began. Every year, the Open University of Great Britain publishes a report on innovations in pedagogy. Last year, British experts identified ten existing innovations that will have the most significant impact on education in the world in the coming years $[1,2,8]$. They are the following:

- Massive open social learning;

- Learning design informed by analytics;

- Flipped classroom that reverses the traditional classroom approach to teaching and learning;

- Bring your own devices;

- Learning to learn;

- Dynamic assessment that focuses on the progress of the student;

- Event-based learning;

- Learning through storytelling;

- Threshold concepts;

- Bricolage as a practical process of learning through tinkering with materials.

\section{Problem Background}

We have chosen the flipped learning method which is used within the blended learning approach. Blended approaches use multiple methods to deliver learning, combining face-to-face interactions with online activities. The balance between the classroom elements and digitally enabled activity varies depending on the design and implementation of the learning. The flexibility inherent in this form of delivery enables teachers to rethink where and how they focus learning activity and students to develop self-directed learning skills and digital literacy. Flipped learning is a pedagogical approach in which the conventional notion of classroom-based learning is inverted, so that students are introduced to the learning material before class, with classroom time then being used to deepen understanding through discussion with peers and problemsolving activities facilitated by teachers.

The application of this approach to schoolchildren seems controversial, since students should have a certain degree of readiness to perceive new material. Mature students on the contrary have sufficient background knowledge, experience of educational and self-educational activity to master new material independently $[5,20,21]$. During practical activity, there is more time to work with the academic text, which is required by the specificity of the subject, aimed at lexical and grammatical composition and structure of academic text analyses, different academic genres comparison and great deal of proofreading and revision.

The phrase "flipped learning" came into general use in the early mid-2000s when it was popularised by chemistry teachers Jon Bergman and Aaron Sams and the founder of the Khan Academy, Salman Khan $[3,4]$. However the concept of flipped learning goes back much further than this. At the International Conference on College Teaching and Learning in 2000 a presentation was delivered on 'The Classroom Flip: Using Web Course Management Tools to Become a Guide by the Side' [19]. It developed the "flip" concept and emphasized the role of Learning Management Systems in delivering materials to students before class. Significantly, the role of the teacher was articulated as the facilitator and coach or "guide on the side". Subsequent research focused on the notion of "inverting the classroom" as a means of providing an inclusive learning environment in which personalized coaching and mentoring was the norm $[14,15]$. The dramatic growth of online content creation, collaboration and distribution tools provide practitioners with an accessible toolkit for delivering flipped learning. There is no doubt that the intersection of web 2.0 technology and learning theory has enabled flipped learning to become a valuable addition to the spectrum of blended learning.

In traditional learning, students acquire knowledge in a classroom context and are then sent away to synthesise, analyse and evaluate this 
after the class. In the flipped classroom, students acquire knowledge before the class and use classroom time to practice and apply concepts and ideas through interaction with peers and teachers. After the class, students reflect upon the feedback they have received and use this to their further learning.

Flipped learning has not been rigorously evaluated as pedagogy in higher education, but case studies are emerging, in ever greater numbers, which document measurable improvements in student and teacher motivation, increased attendance in class, and better grades, as a result of using the flipped approach $[12,13]$.

By providing students with the material to gain a basic level of knowledge and understanding before class, classroom time can be used to deepen learning and develop higher-level cognitive skills. One of the core objectives of flipped learning is to move students away from passive learning and towards active learning where students engage in collaborative activity, peer learning and problembased learning [7]. Within this context, the role of the teacher shifts towards that of facilitator and coach by empowering students to take control of their own learning. The use of technology further enriches the flipped learning process and promotes skills that are essential for 21st century learning for instance digital literacy.

The advantages of this technology are:

- Flexible environment - space, mode of delivery and timelines for learning;

- Learning culture - a learner centred approach to encourage deep learning;

- Intentional content - that maximises learning;

- Professional educator - who guides learning and continuously improves practice.

As for limitations of this approach, Mark Frydenberg notes, "It is not a 'one size fits all' model". He points out that every classroom is different, with different levels of access to technology, different levels of motivation on the part of the students, and different technological knowhow on the part of the instructors [22]. Additionally, teachers must re-learn how to act as the "guide on the side" rather than the "sage on the stage" - and that takes time.

However, whenever the shift does occur, many experts believe the benefits are well worth the effort. According to Association for Supervision and Curriculum Development (ASCD), of 453 teachers who flipped their classrooms, 67 percent reported increased test scores, with particular benefits for students in advanced placement classes and students with special needs; 80 percent reported improved student attitudes, and 99 percent said they would flip their classrooms again next year [16].

\section{Application}

The practical implementation of this method is being carried out within the framework of 5-100 Project in the Center of Academic Writing using the LMS of the Institute of Distant education called Electronic SUSU 2.0. For the course "English language: research paper" - online support was developed. This online course has the following structure: it is divided into 12 weeks; each week covers particular units of the course book. The week section comprises the following:

- Theoretical material in PDF format;

- Academic writing podcasts with PDF version;

- Vocabulary Activities;

- Additional video materials and links.

There is a quiz after each theoretical module. The test is a set of 20-25 multiple choice questions.

Educational process during the semester based on the model of the flipped class was organized as follows: the students studied all the theoretical part of the material at home independently, reading the materials presented in the course in PDF format, watching videos and performing small training tests based on the lesson material. It was also necessary to listen to podcasts for the widening of academic vocabulary and to do interactive vocabulary exercises. So, students came prepared to classes and felt more confident. This was especially appreciated by the students with a lower level of language proficiency. During the classroom, complicated issues of the theory were discussed, and much attention was paid to practical assignments. The emphases was made on students' productive activity in the class such as: finding any possible mistakes in a piece of writing, paraphrasing sentences, putting punctuation in the paragraph, comparing the original and the revised version, various lexical and grammatical exercises. Much attention was paid to the academic texts analysis: work with particular articles and collections of articles. Via this learning platform, students provided their assignments for checking and proofreading. There were: annotated bibliographies, abstracts and literature reviews. Thus, for quite a short course ( 72 hours), the large volume of theoretical material was studied and the students got enough academic 


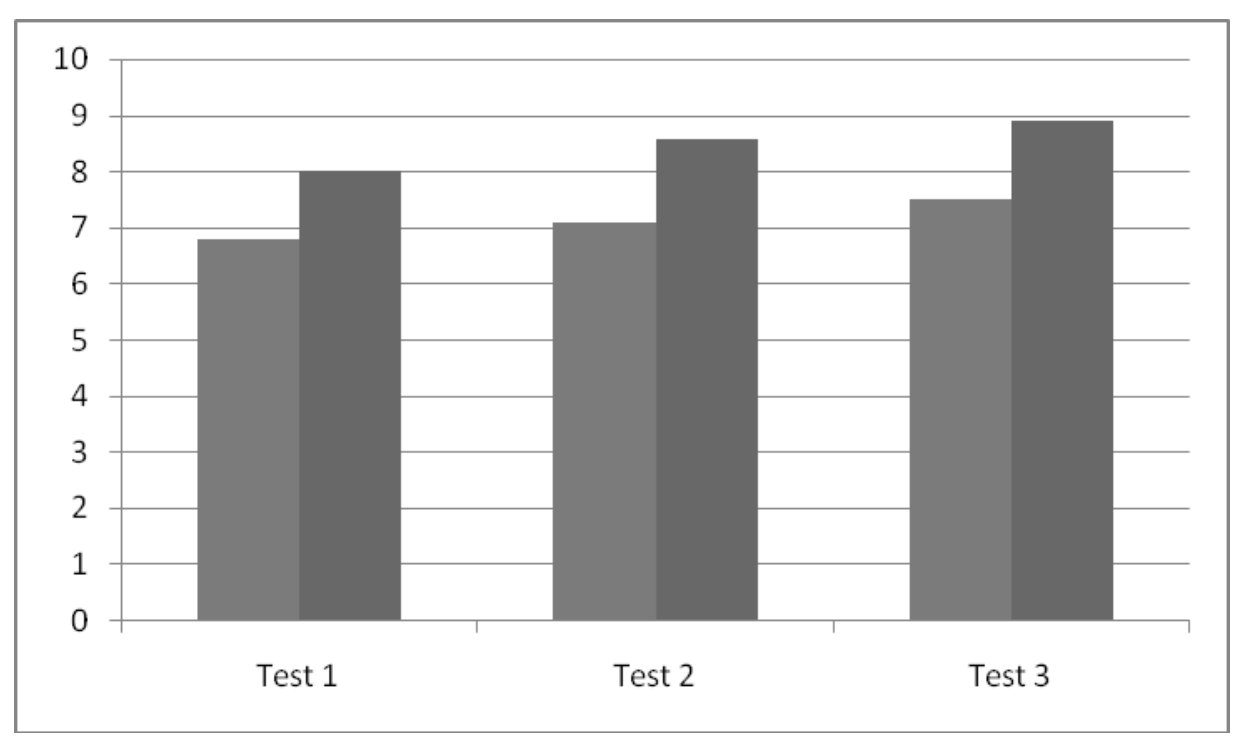

Fig. 1. Progress tests results (average points)

writing practice. Moreover, this approach is beneficial due to the gradual training of all four language aspects. We mean listening, speaking, writing, reading.

Experimental data show that with the same volume of theoretical material (3 modules, 6, 3, 12 units respectively), the number of practical tasks performed in the flipped classroom has doubled. The number of acquired lexical units also increased: with the traditional approach no more than 200 words, with blended learning from 300 to 350 lexical units due to the introduction of interactive lexical exercises. The average percentage of the course mastering in the traditional model is $73.3 \%$, while for the model of flipped class it is $87.75 \%$. It is interesting to note that with the traditional approach, a great differentiation of the results is observed - from 38 to $88 \%$. In the experimental group more homogeneous results were obtained and the percentage of the course mastering is not less than $65 \%$. This, in our opinion, is due to a greater adaptability of the flipped class model. The results of progress tests in the control (blue column) and experimental (red column) groups are shown in Fig. 1

Vodcast technologies (video on demand) can be a promising instrument for this course future development - this is almost the same as the podcast, only with video files and Pre-Vodcasting it is an educational method in which a school teacher or university teacher creates a vodcast with his lecture so that students get an idea of the topic before the lesson on which this topic will be addressed. We are also going to increase the number and variety of interactive exercises and increase the possibilities for giving feedback by using forums and chats. This course can be used not only in the Center of Academic Writing, but also for graduate students and undergraduates.

\section{References}

1. 7 Things You Should Know About Flipped Classrooms. Available at: http://www.educause. edu/library/resources/7-things-you-should-knowabout-flipped-classrooms (accessed 01.04.2018).

2. 10 pedagogicheskikh printsipov, kotorye okazhut samoe znachitel'noe vliyanie na obrazovanie v blizhayshee vremya [10 Principles to Have the Greatest Impact on Education in the Near Future]. Available at: http://www.edutainme. $\mathrm{ru} /$ post/innovation-teaching-2014/ (accessed 01.04.2018).

3. Bishop J., Verleger M. Testing the Flipped Classroom with Model-Eliciting Activities and Video Lectures in a Mid-Level Undergraduate Engineering Course. Frontiers in Education Conference, 2013, pp. 161-163. DOI: 10.1109/ FIE.2013.6684807

4. Bishop J.L., Verleger M.A. The Flipped Classroom: A Survey of the Research. ASEE National Conference Proceedings, 2013, vol. 30, no. 9, pp. 1-18.

5. Boronenko G.F. [Mind Map as an Independent Foreign Language Learning Method]. Nauka YuURGU. Materialy 68-y nauchnoy konferentsii [Science of South Ural State University. Materials of the 68th Scientific Conference]. Chelyabinsk, 2016, pp. 865-870. (in Russ.) 
6. Bryan T., Shestakova L., Volchenkova K.N. A Center for Academic Writing at South Ural State University: Which Model to Choose? 8th International Conference on Education and New Learning Technologies, 2016, pp. 299-307. DOI: 10.21125/edulearn.2016.1055

7. Bryan A., Volchenkova K.N. Blended Learning: Definition, Models, Implications for Higher Education. Bulletin of the South Ural State University. Ser. Education. Educational Sciences, 2016, vol. 8, no. 2, pp. 24-30. DOI: $10.14529 /$ ped 160204

8. Kakie tekhnologii izmenyat shkolu v blizhayshie pyat' let? [What Technologies Are Going to Change Schools in the Next Five Years?] Available at: http://www.edutainme.ru/post/ horizon2014-schools/ (accessed 01.04.2018).

9. Kolova S.M., Yaroslavova E.N. [Realization of Socio-Cultural Component in Foreign Language Education Content of Future Professional Preparation by Means of Information and Communication Technologies]. Applied Linguistics, 2014, vol. 2 (14), pp. 32-41. (in Russ.)

10. Kotlyarova I.O. [Model of the University Teaching Staff Readiness for International Cooperation]. Bulletin of the Chelyabinsk State Academy of Culture and Art, 2015, no. 2 (42), pp. 161-168. (in Russ.)

11. Kotlyarova I.O., Naydanova Yu.V. [Formation of the Personal Mobility in the System of Continuing Education: Review]. Bulletin of the South Ural State University. Ser. Education. Educational Sciences, 2017, vol. 9, no. 2, pp. 6-26. (in Russ.) DOI: 10.14529/ped170201

12. Njie-Carr V.P., Ludeman E., Lee M.C., Dordunoo D., Trocky N.M., Jenkins L.S. An Integrative Review of Flipped Classroom Teaching Models in Nursing Education. Journal of Professional Nursing, 2017, vol. 33, no. 2, pp. 133-144. DOI: 10.1016/j.profnurs.2016.07.001

13. O'Flaherty J., Phillips C. The Use of Flipped Classrooms in Higher Education: A Scoping Review. The Internet and Higher Education, 2015, vol. 25, pp. 5-95. DOI: 10.1016/j.iheduc.2015.02.002

14. Semenova A., Shatalova M. Moskovskie shkoly provedut "perevernutye uroki" [Moscow Schools to Give "Flipped Lessons"]. Available at: http://izvestia.ru/news/561316 (accessed 01.04.2018).
15. Schwartz M. The Flipped Classroom. Available at: https://www.ryerson.ca/content/ dam/lt/resources/handouts/flipped_classroom.pdf (accessed 01.04.2018).

16. Thompson T., Kanuka H. Establishing Communities of Practice for Effective and Sustainable Professional Development for Blended Learning. Effective Blended Learning Practices: Evidence-Based Perspectives in ICT-Facilitated Education: Evidence-Based Perspectives in ICTFacilitated Education, 2009, pp. 144-162. DOI: 10.4018/9781605662961.ch008

17. Tsytovich M.V. Pedagogical Assistance to "Lingva" Program Participants Professional Writing Formation at the Elementary Stage of Language Training. Bulletin of the South Ural State University. Ser. Education. Educational Sciences, 2016, vol. 8, no. 2, pp. 41-47. DOI: $10.14529 /$ ped 160206

18. Tsytovich M.V., Yakusheva O.V. Academic Writing Skills of University Teaching Staff Formation at the Pre-Intermediate Stages of Language Training. 9th Annual International Conference on Technology, Education and Development, 2016. DOI: 10.21125/iceri.2016.0869

19. Tucher B. Flipped Classroom: Online Instruction at Home Frees Class Time for Learning. Education Next, 2012, no. 12 (1), pp. 82-83.

20. Volchenkova K.N. An Andragogical Approach to Forming Faculty Communication Competence in Foreign Language for International Activities. Bulletin of the South Ural State University. Ser. Education. Educational Sciences, 2015, vol. 7, no. 4, pp. 18-25. DOI: $10.14529 /$ ped 150403

21. Volchenkova K.N. Peer Observation as a Tool for Teacher's Professional Development and the Way to Increase the Quality of the Education Process. Bulletin of the South Ural State University. Ser. Education. Educational Sciences, 2016, vol. 8, no. 3, pp. 39-44. DOI: $10.14529 /$ ped 160304

22. Vladimirov A.V., Lebedev Yu.B. Metodika "perevernutogo klassa" $v$ realizatsii trebovaniy FGOS [The Flipped Classroom Approach as a Means of Implementing the Requirements of the Federal Learning Standards]. Available at: http://gov.cap.ru/SiteMap.aspx? gov_id=121\&id=1919130 (accessed 01.04.2018).

Received 31 March 2018 


\title{
ОБУЧЕНИЕ АКАДЕМИЧЕСКОМУ ПИСЬМУ В «ПЕРЕВЕРНУТОМ КЛАССЕ»
}

\author{
М.В. Цытович, Г.Ф. Бороненко \\ Южно-Уральский государственный университет, г. Челябинск, Россия
}

\begin{abstract}
В условиях формирования единого мирового образовательного пространства первостепенным направлением в деятельности университетов и других высших образовательных учреждениях становится международное сотрудничество, базирующееся на принципе академической мобильности. Необходимым условием международного сотрудничества в образовании является владение английским языком. Для разрешения противоречия между потребностью в академической мобильности и низким уровнем владения языком в образовательных учреждениях создаются различные курсы языковой подготовки. В ЮУрГУ были открыты образовательные программы «Лингва», «Офис Академического письма» и другие курсы для преподавателей, аспирантов и магистрантов.

Преподавание на них ведется по традиционной методике и с использованием инновационных технологий. Целью статьи является анализ существующих передовых технологий и подходов к преподаванию языка и обоснование выбора технологий смешанного обучения академическому письму в вузе. В статье раскрывается суть технологии перевернутого класса, ее достоинства и недостатки.

Авторы описывают опыт применения технологии перевернутого класса при обучении написанию научных статей профессорско-преподавательского состава университета.

Ключевые слова: академическая мобильность, смешанное обучение, перевернутый класс, международное сотрудничество, академическое письмо.
\end{abstract}

\section{Лumepamypa}

1. 7 Things You Should Know About Flipped Classrooms. - http://www.educause.edu/library/ resources/7-things-you-should-know-about-flipped-classrooms (дата обращения: 01.04.2018).

2. 10 педагогических принципов, которые окажут самое значительное влияние на образование в ближайшее время. - http://www.edutainme.ru/post/innovation-teaching-2014/ (дата обращения: 01.04.2018).

3. Bishop, J. Testing the Flipped Classroom with Model-Eliciting Activities and Video Lectures in a Mid-Level Undergraduate Engineering Course / J. Bishop, M. Verleger // Frontiers in Education Conference. - 2013. - P. 161-163. DOI: 10.1109/FIE.2013.6684807

4. Bishop, J.L. The Flipped Classroom: A Survey of the Research / J.L. Bishop, M.A. Verleger // ASEE National Conference Proceedings. - 2013. - Vol. 30, no. 9. - P. 1-18.

5. Бороненко Г. Ф. Mind тар как метод самостоятельной внеаудиторной работы при изучении иностранного языка / Г.Ф. Бороненко // Наука ЮУРГУ. Материалы 68-й научной конференции. - Челябинск: 2016. - С. 865-870.

6. Bryan, T. A Center for Academic Writing at South Ural State University: Which Model to Choose? / T. Bryan, L. Shestakova, K.N. Volchenkova // 8th International Conference on Education and New Learning Technologies. - 2016. - P. 299-307. DOI: 10.21125/edulearn.2016.1055

7. Bryan, A. Blended Learning: Definition, Models, Implications for Higher Education / A. Bryan, K.N. Volchenkova // Bulletin of the South Ural State University. Ser. Education. Educational Sciences. 2016. - Vol. 8, no. 2. - P. 24-30. DOI: 10.14529/ped160204

8. Какие технологии изменят школь в ближайшие пять лет? - http://www.edutainme.ru/post/ horizon2014-schools/ (дата обращения: 01.04.2018).

9. Колова, С.М. Реализаџия сочиокультурного компонента содержания иноязычного образования будущего профессионала средствами информационно-коммуникационных технологий । С.М. Колова, Е.Н. Ярославова // Вопросы прикладной лингвистики. - 2014. - № 2 (14). - С. 32-41. 
10. Котлярова, И.О. Модель развития готовности профессорско-преподавательского состава университета к международному сотрудничеству / И.О. Котлярова // Вестник культурь и искусств. - 2015. - № 2 (42). - C. 161-168.

11. Котлярова, И.О. Формирование мобильности личности в системе непрерывного образования: обзор / И.О. Котлярова, Ю.В. Найданова // Вестник ЮУрГУ. Серия «Образование. Педагогические науки». - 2017. - T. 9, № 2. - C. 6-26. DOI: 10.14529/ped170201

12. An Integrative Review of Flipped Classroom Teaching Models in Nursing Education / V.P. Njie-Carr, E. Ludeman, M.C. Lee et al. // Journal of Professional Nursing, 2017. - Vol. 33, no. 2. P. 133-144. DOI: 10.1016/j.profnurs.2016.07.001

13. O'Flaherty, J. The Use of Flipped Classrooms in Higher Education: A Scoping Review / J. O'Flaherty, C. Phillips // The Internet and Higher Education. - 2015. - Vol. 25. - P. 5-95. DOI: 10.1016/j.iheduc.2015.02.002

14. Семенова, А. Московские школы проведут «перевёрнутые уроки» / А. Семенова, М. Шаталова. - http://izvestia.ru/news/561316/.http://izvestia.ru/news/561316 (дата обрамения: 01.04.2018).

15. Schwartz, M. The Flipped Classroom / M. Schwartz. - https://www.ryerson.ca/content/dam/lt/ resources/handouts/flipped_classroom.pdf(дата обращения: 01.04.2018).

16. Thompson, T. Estäblishing Communities of Practice for Effective and Sustainable Professional Development for Blended Learning / T. Thompson, H. Kanuka // Effective Blended Learning Practices: Evidence-Based Perspectives in ICT-Facilitated Education: Evidence-Based Perspectives in ICTFacilitated Education. - 2009. - P. 144-162. DOI: 10.4018/9781605662961.ch008

17. Tsytovich, M.V. Pedagogical Assistance to "Lingva" Program Participants Professional Writing Formation at the Elementary Stage of Language Training / M.V. Tsytovich // Bulletin of the South Ural State University. Ser. Education. Educational Sciences. - 2016. - Vol. 8, no. 2. - P. 41-47. DOI: 10.14529/ped160206

18. Tsytovich, M.V. Academic Writing Skills of University Teaching Staff Formation at the PreIntermediate Stages of Language Training / M.V. Tsytovich, O.V. Yakusheva // 9th Annual International Conference on Technology, Education and Development. - 2016. DOI: 10.21125/iceri.2016.0869

19. Tucher, B. Flipped Classroom: Online Instruction at Home Frees Class Time for Learning / B. Tucher // Education Next. - 2012. - No. 12 (1). - P. 82-83.

20. Volchenkova, K.N. An Andragogical Approach to Forming Faculty Communication Competence in Foreign Language for International Activities / K.N. Volchenkova // Bulletin of the South Ural State University. Ser. Education. Educational Sciences. - 2015. - Vol. 7, no. 4. - P. 18-25. DOI: 10.14529/ped150403

21. Volchenkova, K.N. Peer Observation as a Tool for Teacher's Professional Development and the Way to Increase the Quality of the Education Process / K.N. Volchenkova // Bulletin of the South Ural State University. Ser. Education. Educational Sciences. - 2016. - Vol. 8, no. 3. - P. 39-44. DOI: 10.14529/ped160304

22. Владимиров, А.В. Методика «перевёрнутого класса» в реализаиии требований ФГОС / А.В. Владимиров, Ю.Б. Лебедев. -http://gov.cap.ru/SiteMap.aspx?gov_id=121\&id=1919130/(дата обращения: 01.04.2018).

Цытович Мария Витальевна, кандидат педагогических наук, доцент кафедры иностранных языков, Южно-Уральский государственный университет, г. Челябинск, Maria.Tsytovich@gmail.com.

Бороненко Галина Федоровна, старший преподаватель кафедры иностранных языков, Южно-Уральский государственный университет, г. Челябинск, gboronenko@yandex.ru.

Поступила в редакцию 31 марта 2018 г.

\section{ОБРАЗЕЦ ЦИТИРОВАНИЯ}

Tsytovich, M.V. Teaching Academic Writing in a Flipped Classroom / M.V. Tsytovich, G.F. Boronenko // Вестник ЮУрГУ. Серия «Образование. Педагогические науки». 2018. - T. 10, № 2. - C. 59-65. DOI: 10.14529/ped180208

\section{FOR CITATION}

Tsytovich M.V., Boronenko G.F. Teaching Academic Writing in a Flipped Classroom. Bulletin of the South Ural State University. Ser. Education. Educational Sciences. 2018, vol. 10, no. 2, pp. 59-65. DOI: $10.14529 /$ ped 180208 